Sains Malaysiana 49(4)(2020): 941-952

http://dx.doi.org/10.17576/jsm-2020-4904-23

\title{
Defaultable Bond Pricing under the Jump Diffusion Model with Copula Dependence Structure
}

(Penentuan Harga Bon Boleh Mungkir di Bawah Model Resapan Lompat dengan Struktur Kebersandaran Kopula)

\author{
SiTI NORAFIDAH MOHD RAMLI* \& JiWOOK JANG
}

\begin{abstract}
We study the pricing of a defaultable bond under various dependence structure captured by copulas. For that purpose, we use a bivariate jump-diffusion process to represent a bond issuer's default intensity and the market short rate of interest. We assume that each jump of both variables occur simultaneously, and that their sizes are dependent. For these simultaneous jumps and their sizes, a homogeneous Poisson process and three copulas, which are a Farlie-GumbelMorgenstern copula, a Gaussian copula, and a Student t-copula are used, respectively. We use the joint Laplace transform of the integrated risk processes to obtain the expression of the defaultable bond price with copula-dependent jump sizes. Assuming exponential marginal distributions, we compute the zero coupon defaultable bond prices and their yields using the three copulas to illustrate the bond. We found that the bond price values are the lowest under the Student-t copula, suggesting that a dependence structure under the Student-t copula could be a suitable candidate to depict a riskier environment. Additionally, the hypothetical term structure of interest rates under the risky environment are also upward sloping, albeit with yields greater than 100\%, reflecting a higher compensation required by investors to lend funds for a longer period when the financial market is volatile.
\end{abstract}

Keywords: Bivariate jump-diffusion model; credit risk; default intensity; short rate; zero coupon bond

ABSTRAK

Kertas ini mengkaji penentuan harga bon boleh mungkir dengan kadar faedah pendek dan nilai keamatan ingkar penerbit bon, dengan struktur kebersandaran yang diwakili oleh kopula. Untuk tujuan itu, proses resapan-lompat bivariat digunakan untuk mewakili proses keamatan ingkar penerbit bon dan kadar faedah pendek pasaran. Setiap lompatan oleh kedua-dua pemboleh ubah diandaikan berlaku serentak, dan saiznya adalah bersandaran antara satu sama lain. Bagi mewakili proses lompatan serentak dan struktur kebersandaran saiznya, proses Poisson yang homogen dan tiga kopula, iaitu kopula Farlie-Gumbel-Morgenstern, Gaussian, dan student-t digunakan. Transformasi Laplace tercantum bagi proses risiko bersepadu digunakan untuk mendapatkan persamaan harga bon boleh mungkir dengan saiz lompatan faktor yang bersandar dengan struktur kopula. Harga bon boleh mungkir tanpa kupon dan kadar hasilnya dihitung di bawah tiga jenis kopula dengan taburan marginal eksponen untuk mewakili kebersandaran antara kedua-dua faktor. Kajian mendapati bahawa nilai harga bon adalah yang paling rendah apabila faktor kebersandaran digambarkan oleh kopula student-t, yang menunjukkan bahawa struktur kebersandaran di bawah kopula student- $t$ adalah lebih sesuai untuk menggambarkan persekitaran yang berisiko berbanding kopula FGM dan Gaussian. Di samping itu, walaupun struktur masa kadar faedah bagi jangka panjang di bawah persekitaran yang berisiko juga menunjukkan pola menaik, kadar hasil yang melebihi 100\%, mencerminkan situasi bahawa pelabur memerlukan pampasan yang lebih tinggi bagi aktiviti meminjamkan dana untuk tempoh yang lebih lama apabila situasi pasaran kewangan adalah tidak menentu.

Kata kunci: Bon sifar kupon; kadar keamatan mungkir; kadar pendek; model resapan-lompat bivariat; risiko kredit

\section{INTRODUCTION}

After a decade since the 2008 Global Financial Crisis (GFC), the overall measures of US household financial wellness show that many households remain vulnerable with increasing auto loan, student debts as well as credit card debt although the household debt to GDP ratio has reduced by $19 \%$. An extended period of low interest rates has also witnessed global nonfinancial corporate debt doubled, hitting $\$ 66$ trillion for the past 10 years.
Furthermore, the global public debt has soared to $\$ 60$ trillion, at an average of $105 \%$ of GDP among the advanced economies and $46 \%$ among the emerging economies (Lund et al. 2018). Therefore, it is necessary to develop prudent quantitative models for corporate bonds pricing given the extent of the interest rate risk exposure to the economic agents, despite the allegations that mathematical models were the reason for the losses borne during the GFC (Donelly \& Embrechts 2010; Salmon 2009; Stewart 2012). 
The two classes of models in credit risk evaluation for corporate debt pricing are the structural model and the reduced form model. Under the structural approach, a firm's liabilities are viewed as contingent claims issued against its assets, with all the payoffs to the firm's liabilities in bankruptcy completely specified (Black \& Cox 1976; Merton 1974). In other words, bankruptcy is viewed as the event when the firm's asset value hits a prespecified boundary. The view undertaken in this class of models was then ameliorated in Hull and White (1995) as well as Longstaff and Schwartz (1995), whereby the cash flows to risky debt were exogenously specified as a given fraction of each promised dollar in the event of bankruptcy. This perspective would be useful when considering the complex priority structure of payoffs made to a firm's liabilities. Ruf and Scherer (2011) then computed the bond prices following a structural default model with jumps using Monte Carlo simulation based on a Brownian bridge algorithm.

Rather than examining the firm's internal structure whose complete information is not available to the external parties as in the structural approach, we work under the reduced form approach which requires a different set of information that is less refined. We refer the readers to Jarrow and Protter (2004) for a thorough discussion on the comparison between the structural and the reduced form models. Under the reduced form approach, we observe the information generated by a vector of state variables and the firm's default time. The firm's default time was generated by a Cox process with an intensity process that also depends on the state variables. Lando (1998) prepared a convenient framework that allows for dependencies between default intensities and state variables, whereby the Cox process was used to model the (stopping) time when the rating changed until the issuer went default in the last state of a generalized K-states Markovian model. In one of the earliest papers to promote the term 'reduced-form' approach, Duffie and Singleton (1999) treated default as an unpredictable event governed by the external hazard rate process. A contingent claim that is subject to default risk can be priced just like the default-free claim simply by replacing the short rate with the default-adjusted short rate process under an equivalent martingale measure in an arbitrage free framework. This approach was then extended in Kijima (2000) which considered the possibility of default-event triggers that cause joint default, and in Jarrow and $\mathrm{Yu}$ (2001) which introduced the concept of counterparty risk to capture the economy-wide and inter-firm linkages.

Previous studies of the reduced form approach have taken several directions in researchers' attempts to incorporate default correlation and multiple defaults (Brigo \& Chourdakis 2009; Herbertsson et al. 2011; Jang 2007; Ma \& Kim 2010). The reduced form model promoted in Jarrow and Turnbull (1995) was further developed in Jarrow et al. (1997), whereby the bankruptcy process was modelled as a continuous time Markov process with discrete state space representing the firm's credit ratings. By combining the structural and the reduced form approaches, the authors specified the credit event exogenously and allowed the bankruptcy assumptions to be imposed only on observables (i.e. the firm's credit ratings) as opposed to the firm's asset values. Another hybrid example can also be found in HyongChol and Ning (2005), which assumed an expected and unexpected default following stochastic default intensity and provided an explicit pricing formula for defaultable bond and credit default swap (CDS).

Another approach to incorporate default dependence between related parties is through the use of copulas (Giesecke 2004; Jouanin et al. 2001; Li 2000; Schonbucher \& Schubert 2001). The use of Farlie-Gumbel-Mogenstern (FGM) copula to price a CDS using the multivariate shot noise process was studied in Ma and Kim (2010) and extended by Mohd Ramli and Jang (2015) by adding a diffusion term on the shot noise process making it a multivariate jump-diffusion process. A study by Jang and Mohd Ramli (2018) applied the joint survival probability expression to examine the effect of the jump-diffusion process on a social benefit scheme consisting of life insurance, as well as unemployment/ disability and retirement benefits. Hence in this paper, we propose the jump diffusion process to represent the risky environment of a financial market via the short interest rate and the bond issuer's default intensity. Due to the strong evidence that the default intensity varying with the business cycle (Kijima 2000), we aim to examine the bond price behaviour under the risky environment represented by the jump diffusion process using three types of two-tailed copula, which also allows flexibility in modelling the variables and its combined effect.

The remaining of the paper is organized as follows: Next section defines the bivariate jump-diffusion process for short rate and firm's default intensity, and the three copulas used to capture the dependence between the jump sizes of the variables, i.e. the FGM, Gaussian and student's t-copula. The expression of the bond price obtained from the results in Mohd Ramli and Jang (2015) was also presented. This is then followed by a numerical example in subeseqent section showing the computation and the comparison of bond prices and their yields under the three copulas, showcasing the advantage of the Student-t copula over the other two copulas considered. Final section concludes the paper.

\section{Methods}

This section describes the quantitative model used to represent the important variables used in the defaultable bond pricing, and the three copulas used to illustrate the dependence structure.

\section{BIVARIATE JUMP DIFFUSION MODEL}

For $i=1$ (bond issuer's default intensity) and $i=2$ (short rate), the jump-diffusion Cox-Ingersoll-Ross (CIR) process considered has the following structure: 


$$
\begin{aligned}
& d \lambda^{(i)}(t)=c^{(i)}\left(b^{(i)}+a^{(i)} \lambda^{(i)}(t)\right) d t+\sigma^{(i)} \sqrt{\lambda^{(i)}(t)} d W^{(i)}(t) \\
& +d L^{(i)}(t)
\end{aligned}
$$$$
\text { with } \quad L^{(i)}(t)=\sum_{h=1}^{M^{(i)}(t)} Y_{h}^{(i)} \text {, }
$$

where $c^{(\mathrm{i})} b^{(\mathrm{i})}$ represents the long-term mean level of the short rate or default intensity; $c^{(\mathrm{i})} a^{(\mathrm{i})}$ represents the drift coefficient, which is the speed at which the factor is driven back to its long-term mean, with $c^{(\mathrm{i})} a^{(\mathrm{i})}<0 ; \sigma^{(\mathrm{i})}$ is the diffusion coefficient; and $W^{(\mathrm{i})}(\mathrm{t})$ is a standard Brownian motion governing the process.

We define $L^{(\mathrm{i})}(\mathrm{t})$ as a pure jump process in which $M^{(\mathrm{i})}(\mathrm{t})$ is the number of jumps, representing the total number of events up to time $t$ and $\mathrm{Y}_{\mathrm{h}}{ }^{(\mathrm{i})}, h=1,2, \cdots, M^{(\mathrm{i})}$ (t) is their sizes. The point process $M^{(\mathrm{i})}(\mathrm{t})$ with average $\rho^{(i)}$ is independent of the vector sequence of jump sizes. The jump occurrences are assumed to be simultaneous for both processes and that their sizes are independent and identically distributed (i.i.d.) with distribution function $F^{(\mathrm{i})}(\mathrm{y})$. The process needs to satisfy the usual feller condition given by $\frac{2 c^{(i)} b^{(i)}}{a^{(i)}}>\sigma^{(i)^{2}} \$$ to ensure $\lambda^{(\mathrm{i})}$ $(t)>0$. Note that, by setting $\rho^{(\mathrm{i})}=0$, the jump diffusion process becomes the celebrated Cox-ingersoll-Ross (CiR) process (Cox et al. 1985), while setting $\sigma^{(\mathrm{i})}=0$ gives us the shot noise process (Jang 2007; Ma \& Kim 2010). The presence of the diffusion and jump terms make the jump diffusion process a more suitable candidate to represent a risky economic environment, relative to the CiR model (1985) and the shot noise processes.

\section{Defaultable Bond Price Expression}

Using the multivariate joint Laplace transform proposed in Mohd Ramli and Jang (2015), we obtain the expression for a defaultable bond price, $\mathbb{E}\left[e^{-\int_{0}^{t}\left(d_{s}+r_{s}\right) d s}\right]$, whereby the $d_{s}$ denotes the default rate of the issuer and $r_{s}$ denotes the interest rates. The joint Laplace transform is useful to compute the survival probability of an insured life given an insurance contract, as well as the bond price.

As there are two variables involved, we let $n=2$ whereby $i=1$ is the obligor's default intensity and $i=2$ is the market short rate. for each process, we also define its cumulative hazard process, $\Lambda^{(\mathrm{i})}(\mathrm{t})=\lambda^{(\mathrm{i})}(\mathrm{s}) d s$, which is the sum of risks related to the process $i$ that we encounter from time 0 to $t$. a s proposed and proven in Corollary 2 of Mohd Ramli and Jang (2015), the joint Laplace transform up to time $t$ described by the filtration $\mathcal{G}_{t}=\sigma$ $\left\{\left(\lambda^{(1)}(\mathrm{s}), \lambda^{(2)}(\mathrm{s})\right): s \leq t\right\} \in \mathfrak{R}^{n}$ is given by the following proposition:

Proposition 1 Considering constants $\alpha^{(\mathrm{i})} \geq 0$ and $\gamma^{(\mathrm{i})} \geq 0$ for $\mathrm{i}=1,2$, the joint Laplace transform of the vector $\left(\Lambda^{(1)}(\mathrm{t}), \Lambda^{(2)}(\mathrm{t}), \lambda^{(1)}(\mathrm{t}), \lambda^{(2)}(\mathrm{t})\right)$ is given by

$$
\begin{aligned}
& \mathbb{E}\left[\exp \left\{-\sum_{i=1}^{2} \gamma^{(i)} \Lambda^{(i)}(t)+\alpha^{(i)} \lambda^{(i)}(t)\right\} \mid \mathcal{G}_{0}\right] \\
= & \prod_{i=1}^{2}\left[\mathrm{H}^{(i)}(t)^{\frac{\left.2 c^{(i)}\right)^{(i)}}{\sigma^{(i)}}}\right] \exp \left(-\sum_{i=1}^{2} \mathrm{G}^{(i)}(t) \lambda^{(i)}(0)+\rho^{(i)}\right. \\
& {\left.\left[\int_{0}^{t} 1-\hat{c}\left(\mathrm{G}^{(1)}(s), \mathrm{G}^{(2)}(s)\right)\right] d s\right) }
\end{aligned}
$$

where $\mathrm{t}>0$, with

$$
\begin{aligned}
& \mathrm{g}^{(\mathrm{i})}(t)= \frac{\alpha^{(i)}\left[\left(\mathrm{D}^{(i)}+\mathrm{c}^{(i)} \mathrm{a}^{(i)}\right)+\mathrm{D}^{(i)}-\mathrm{c}^{(i)} \mathrm{a}^{(i)} \exp \left\{-\mathrm{D}^{(i)} t\right\}\right]+}{\sigma^{(i)(2)} \alpha^{(i)}\left(1-\exp \left\{-\mathrm{D}^{(i)} t\right\}\right)+\left(\mathrm{D}^{(i)}-\mathrm{c}^{(i)} \mathrm{a}^{(i)}\right)+} \\
& \frac{2 \gamma^{(i)}\left(1-\exp \left\{-\mathrm{D}^{(i)} \mathrm{t}\right\}\right)}{\left(\mathrm{D}^{(i)}+\mathrm{c}^{(i)} \mathrm{a}^{(i)}\right) \exp \left\{-\mathrm{D}^{(i)} \mathrm{t}\right\}} \\
& \mathrm{H}^{(\mathrm{i})}(t)= \frac{2 \mathrm{D}^{(i)} \exp \left\{-\frac{\left(\mathrm{D}^{(i)}+\mathrm{c}^{(i)} \mathrm{a}^{(i)}\right)}{2} t\right\}}{\sigma^{(i)^{2}} \alpha^{(i)}\left(1-\exp \left\{-\mathrm{D}^{(i)} t\right\}\right)+\left(\mathrm{D}^{(i)}-\mathrm{c}^{(i)} \mathrm{a}^{(i)}\right)+} \\
&\left(\mathrm{D}^{(i)}+\mathrm{c}^{(i)} \mathrm{a}^{(i)}\right) \exp \left\{-\mathrm{D}^{(i)} \mathrm{t}^{\}}\right. \\
& \mathrm{D}^{(i)}=\sqrt{\left(\mathrm{c}^{(i)} \mathrm{a}^{(i)}\right)^{2}+2 \gamma^{(i)} \sigma^{(i)}}
\end{aligned}
$$

and

$$
\begin{aligned}
\hat{c}\left(\xi^{(1)}, \xi^{(2)}\right)= & \int_{0}^{\infty} \int_{0}^{\infty} \exp \left\{-\sum_{i=1}^{2} \xi^{(i)} y_{i}\right\} \frac{\partial^{2} C\left(F_{Y^{(1)}}\left(y_{1}\right), F_{Y^{(2)}}\left(y_{2}\right)\right)}{\partial y_{1} \partial y_{2}} \\
& d y_{1} d y_{2} .
\end{aligned}
$$

Note that the bivariate joint Laplace transform contains a random element given by the term $\widehat{c}\left(\xi^{(1)}, \xi^{(2)}\right)$, which incorporates the jump-size distribution and the dependence structure between the jump sizes of the variables. Setting $\alpha^{(i)}=0$ in (2), we obtain the bond price expression, as presented in the following proposition:

Proposition 2 The joint Laplace transform of the vector $\left(\Lambda^{(1)}(t), \Lambda^{(2)}(t)\right)$ is given by

$$
\begin{aligned}
& \mathbb{E}\left[\exp \left\{-\sum_{i=1}^{2} \gamma^{(i)} \Lambda^{(i)}(t)\right\} \mid \mathcal{G}_{0}\right] \\
= & \prod_{i=1}^{2}\left[\mathrm{~J}^{(i)}(t)^{\frac{2 c^{(i)} b^{(i)}}{\sigma^{(i)^{2}}}}\right] \exp \left(-\sum_{i=1}^{2} \mathrm{~K}^{(i)}(t) \lambda^{(i)}(0)+\rho^{(i)}\right. \\
& \left.\rho^{(i)}\left[\int_{0}^{t} 1-\hat{c}(K(s), K(s))\right] d s\right),
\end{aligned}
$$

where $\mathrm{t}>0$, with 


$$
\begin{aligned}
& \mathrm{K}^{(i)}(t)=\frac{2 \gamma^{(i)}\left(1-\exp \left\{-\mathrm{D}^{(i)} t\right\}\right)}{\left(\mathrm{D}^{(i)}-\mathrm{c}^{(i)} \mathrm{a}^{(i)}\right)+\left(\mathrm{D}^{(i)}+\mathrm{c}^{(i)} \mathrm{a}^{(i)}\right) \exp \left\{-\mathrm{D}^{(i)} t\right\}}, \quad C_{v}^{t}\left(u_{1}, u_{2}\right)=\int_{-\infty}^{t_{v}^{-1}\left(u_{1}\right)} \int_{-\infty}^{t_{v}^{-1}\left(u_{2}\right)} \frac{\Gamma\left(\frac{v+2}{2}\right)}{\Gamma\left(\frac{v}{2}\right) \sqrt{(\pi v)^{2}|\Theta|}}\left(1+\frac{\eta^{T} \Theta^{-1} \eta}{v}\right) \\
& \mathrm{J}^{(i)}(t)=\frac{2 \mathrm{D}^{(i)} \exp \left\{-\frac{\left(\mathrm{D}^{(i)}+\mathrm{c}^{(i)} \mathrm{a}^{(i)}\right)}{2} t\right\}}{\left(\mathrm{D}^{(i)}-\mathrm{c}^{(i)} \mathrm{a}^{(i)}\right)+\left(\mathrm{D}^{(i)}+\mathrm{c}^{(i)} \mathrm{a}^{(i)}\right) \exp \left\{-\mathrm{D}^{(i)} t\right\}} .
\end{aligned}
$$

where $u_{i} \epsilon[0,1]$ for $i=1,2$, and the correlation parameter $\theta \epsilon[-1,1]$. For the $g$ aussian and student-t copulas, the correlation parameter is contained in the correlation matrix $\Theta=\left[\begin{array}{ll}1 & \theta \\ \theta & 1\end{array}\right]$. We also define the vectors $\omega=\left[\omega_{1} \omega_{2}\right]^{T}$ and $\boldsymbol{\eta}=\left[\eta_{1} \eta_{2}\right]^{T}$ where $\omega_{i}=\Phi^{-1}\left(u_{i}\right)$ and $\eta i=t_{v}{ }^{-1}\left(u_{i}\right)$ are the inverse $g$ aussian and inverse Student-t distribution with degrees of freedom, respectively, taken on the variables $u_{\mathrm{i}}$. While any distribution can be considered for the marginal distributions of $\mathrm{Y}^{(\mathrm{i})}$ in the vector of jumps $\left(\mathrm{Y}^{(1)}, \mathrm{Y}^{(2)}\right)$, only the continuous marginals will ensure a uniquely defined copula distribution (see the Sklar's theorem in nelsen (2006), and Shamiri et al. (2011) for example). In this study, the jump size variables are assumed to follow the exponential marginal for simplicity of illustration.

The FGM copula is used in this study for its simplicity and analytical tractability which allows for the closedform expressions to be easily derived. However, due to the weak dependence structure under the FGM copula, we propose to examine the bond price and yield under another two sided copulas, i.e. copula with dependence structure $\theta \in[-1,1]$, which are the gaussian and the Student-t copulas. The g aussian copula was commonly used prior to the GFC 2008, while the Student-t copula is chosen as a potential candidate to represent the risky environment. In other words, the Student-t copula was chosen to incorporate the impact of higher frequency of concurring and opposing joint jump sizes, given its ability to capture variables with extreme values. Readers are referred to Mohd Ramli and Jang (2015) for the graphical illustrations of the three copulas when applied to two simulated processes. However, since the elliptical copulas do not admit analytical expression when combined with the chosen marginals, we evaluate the bond price numerically.

\section{RESULTS AND DISCUSSION}

Now we examine the behaviour of the defaultable zero coupon bond prices under three different copulas mentioned in Methods section. The hypothetical defaultable bond pays redemption value $\$ 100$ at maturity. for simplicity, we assume that the jump sizes of both the bond issuer's default intensity $(i=1)$ and the market short rate $(i=2)$ are exponentially distributed. The defaultable bond price values $\mathrm{P}_{\mathrm{t}}$ are computed using (7), and the bond yield $d_{\mathrm{t}}$ is obtained using the following formula:

$$
d_{t}=\left(\frac{\text { Future Value }}{P_{t}}\right)^{\frac{1}{T-t}}-1
$$

We examine two scenarios whereby the exponential jump size parameters, $\left(\mu^{(1)}, \mu^{(2)}\right)$ are assigned the values 
$\left(\mu_{t}^{(1)}=100, \mu_{t}^{(2)}=200\right)$ and $\left(\mu_{t}^{(1)}=5, \mu_{t}^{(2)}=10\right)$. The first set of parameters represents a safer environment due to low average jump sizes ( $\frac{1}{100}$ and $\frac{1}{200}$ respectively), while the second set denotes a relatively riskier environment with relatively higher average jump sizes ( $\frac{1}{5}$ and $\frac{1}{10}$, respectively). We assume an average of 4 jump occurrences per year (i.e. $\rho=4$ ) and that the long term mean value for the issuer's default intensity and the market short rate $=0$. Furthermore, to represent the relatively secure nature of a financial market relative to an issuer, we also assume that $\mathrm{c}^{(1)}<\mathrm{c}^{(2)}$ (i.e. the market short rate process reverts to its long term mean quicker than the default intensity process) and $\sigma^{(1)}>\sigma^{(2)}$ (i.e. default intensity process is more volatile than the market short rate process). The value of other parameters are summarized in Table 1 . The degrees of freedom $v=3$ are used to compute the bond price under the Student- $t$ copula with one-year maturity. The bond price values for maturity $>1$ year can be found in the Appendix section.

TABLE 1. Parameter values of bond issuer's default intensity and short rate

\begin{tabular}{ccccccc}
\hline & $c^{(i)}$ & $\alpha^{(i)}$ & $b^{(i)}$ & $\sigma^{(i)}$ & $\rho^{(i)}$ & $\lambda_{0}^{(i)}$ \\
\hline Issuer (1) & 3 & -1 & 0 & 0.5 & 4 & 0.5 \\
Short rate & 0.5 & -1 & 0 & 0.4 & 4 & 0.0025
\end{tabular}

Table 2 exhibits the bond price for each scenario with the corresponding yield in Table 3. The term 'Range' in Table 2 denotes the difference between the bond prices given by $\theta^{0.95}$ and $\theta^{-0.95}$, i.e. Price ${ }^{\theta=-0.95}-$ Price $^{\theta=+0.95}$.

TABLE 2. Zero coupon bond price under various copulas for $\mathrm{t}=1$

\begin{tabular}{ccccccc}
\hline & \multicolumn{3}{c}{$\mu_{\mathrm{t}}^{(1)}=100$ and $\mu_{\mathrm{t}}^{(2)}=200$} & \multicolumn{3}{c}{$\mu_{\mathrm{t}}^{(1)}=5, \mu_{\mathrm{t}}^{(2)}=10$} \\
$\theta$ & FGM & Gaussian & Student-t & FGM & Gaussian & Student-t \\
\hline-0.95 & 92.627 & 92.529 & 89.424 & 57.797 & 57.359 & 51.019 \\
-0.9 & 92.627 & 92.530 & 89.564 & 57.810 & 57.387 & 51.030 \\
-0.5 & 92.627 & 92.626 & 89.578 & 57.910 & 57.669 & 51.275 \\
0 & 92.628 & 92.628 & 90.002 & 58.036 & 58.036 & 51.867 \\
0.5 & 92.629 & 92.631 & 90.030 & 58.163 & 58.470 & 52.791 \\
0.9 & 92.629 & 92.633 & 90.121 & 58.264 & 58.866 & 53.883 \\
0.95 & 92.629 & 92.634 & 90.151 & 58.277 & 58.870 & 54.065 \\
Range & $-0.2 \%$ & -0.105 & -0.727 & -0.48 & -1.511 & -3.046 \\
\hline
\end{tabular}

We see that as $\theta$ progressed from negative to positive, the bond price figures in Table 2 demonstrate an increasing pattern while the bond yield figure in Table 3 shows a decreasing pattern under all copulas considered. In practice, the 'high yield, low price' pattern is usually seen when examining the price behaviour of a bond with high risk, implying that higher compensation is required to invest for a long period when the market is uncertain. In comparison with the other two copulas, the bond price values are the lowest under the Student- $t$ copula, suggesting that a dependence structure under the Student-t copula could be a good candidate to depict a riskier environment.

TABLE 3. Zero coupon bond price under various copulas for $\mathrm{t}=1$

\begin{tabular}{ccccccc}
\hline & \multicolumn{3}{c}{$\mu_{\mathrm{t}}^{(1)}=100$ and $\mu_{\mathrm{t}}^{(2)}=200$} & \multicolumn{3}{c}{$\mu_{\mathrm{t}}^{(1)}=5, \mu_{\mathrm{t}}^{(2)}=10$} \\
$\theta$ & FGM & Gaussian & Student-t & FGM & Gaussian & Student-t \\
\hline-0.95 & $7.960 \%$ & $8.074 \%$ & $11.827 \%$ & $73.019 \%$ & $74.340 \%$ & $96.006 \%$ \\
-0.9 & $7.960 \%$ & $8.074 \%$ & $11.652 \%$ & $72.982 \%$ & $74.255 \%$ & $95.963 \%$
\end{tabular}




\begin{tabular}{ccccccc}
-0.5 & $7.960 \%$ & $7.961 \%$ & $11.635 \%$ & $72.681 \%$ & $73.405 \%$ & $95.028 \%$ \\
0 & $7.959 \%$ & $7.959 \%$ & $11.109 \%$ & $72.306 \%$ & $72.306 \%$ & $92.802 \%$ \\
0.5 & $7.958 \%$ & $7.956 \%$ & $11.074 \%$ & $71.931 \%$ & $71.029 \%$ & $89.425 \%$ \\
0.9 & $7.957 \%$ & $7.953 \%$ & $10.962 \%$ & $71.632 \%$ & $69.880 \%$ & $85.587 \%$ \\
0.95 & $7.957 \%$ & $7.952 \%$ & $10.925 \%$ & $71.595 \%$ & $69.866 \%$ & $84.961 \%$ \\
\hline
\end{tabular}

Analogously, the bond yields are highest under the Student-t copula and lowest under the FGM copula. Additionally, the yield under Gaussian copula differs by less than $\pm 0.15 \%$ than the FGM counterpart, when the environment is relatively safe. When comparing the bond yield across $\theta$ for both scenarios, we also noticed that the yields for the case of $\left(\mu_{t}^{(1)}=5, \mu_{t}^{(2)}=10\right)$ are much higher than the yields given by the case of $\left(\mu_{t}^{(1)}=100, \mu_{t}^{(2)}=200\right)$ for all copulas considered, i.e. by almost 10 times higher. This is not surprising as lower exponentially distributed jump size parameters indicate a higher average jump size, thereby indicating a relatively risky market environment.

It is also worth noting that the bond price and yield under the Student-t copula is not equal to the bond prices and yields as the Gaussian and FGM copula when $\theta=0$. In contrast to the general theorem of copula, the Student- $t$ copula does not give an independence case when the dependence parameter $\theta=0$, and hence it would not result in product copula (Schmidt 2006).
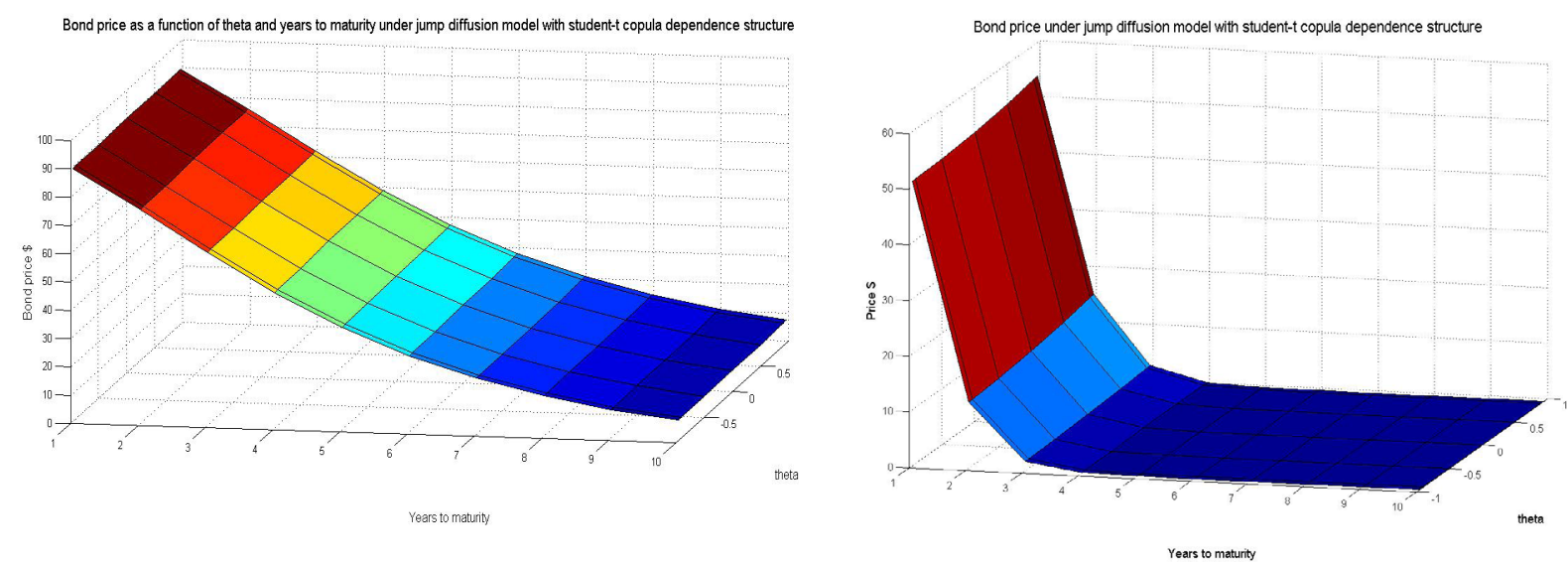

FIGURE 1. Bond price as a function of $\theta$ and maturity under the jump-diffusion model with Student-t copula dependence structure and jump sizes $\left(\mu_{\mathrm{t}}^{(1)}=100, \mu_{\mathrm{t}}^{(2)}=200\right)($ left $)$ and $\left(\mu_{\mathrm{t}}^{(1)}=5, \mu_{\mathrm{t}}^{(2)}=10\right)$ (right)

Figures 1 and 2 show the bond price and bond yield under the jump-diffusion process with the dependence structure captured by the Student-t copula as a function of maturity (T-t) (on the $\mathrm{x}$-axis) and $\theta$ (on the y-axis). Under both scenarios of $\left(\mu_{\mathrm{t}}^{(1)}=100, \mu_{\mathrm{t}}^{(2)}=200\right)$ and $\left(\mu_{\mathrm{t}}^{(1)}=5, \mu_{\mathrm{t}}^{(2)}=10\right)$, the bond price decreased and yield increased as maturity increased reflecting the riskiness of the instrument in the long run which commands higher return for funds kept for a long period up to 10 years. Additionally, in the risky market environment i.e. when the $\left(\mu_{\mathrm{t}}^{(1)}=5, \mu_{\mathrm{t}}^{(2)}=10\right)$, the bond is almost worthless as the term to maturity goes beyond 5 years. The bond price and bond yield under the Gaussian and the FGM copula show a similar pattern (see Appendix). 

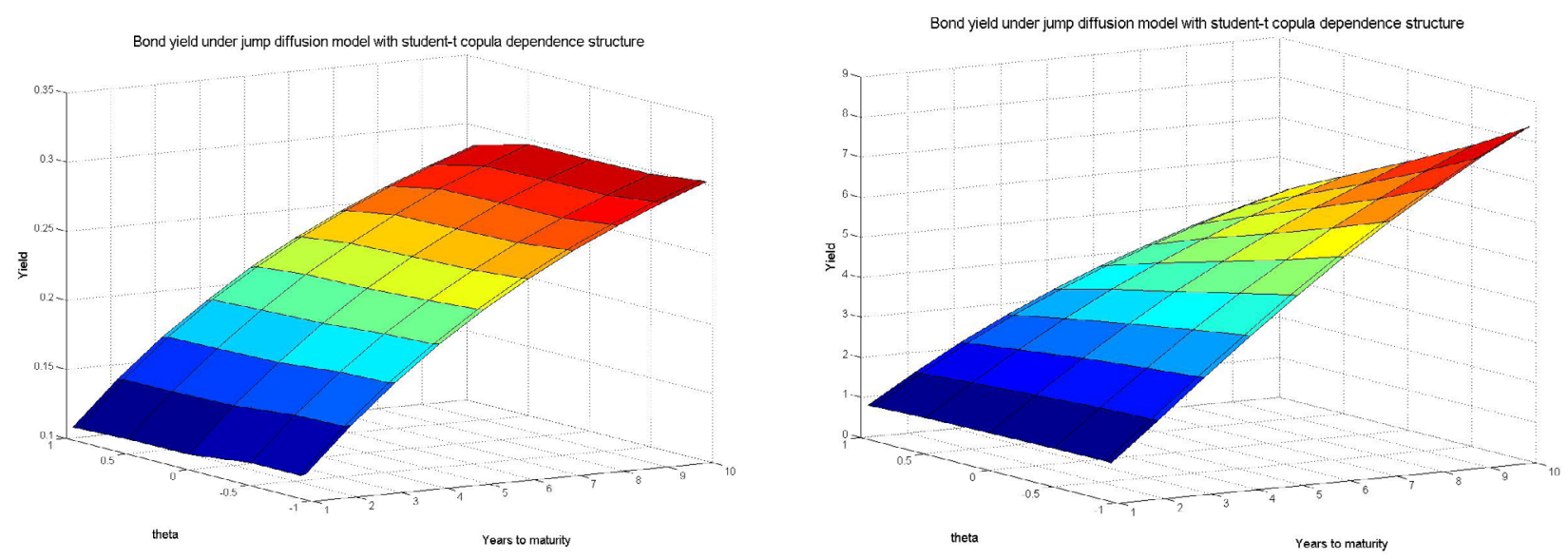

FIGURE 2. Bond yield as a function of $\theta$ and maturity under the jump-diffusion model with Student-t copula dependence structure and jump sizes $\left(\mu_{t}^{(1)}=100, \mu_{t}^{(2)}=200\right)$ (left) and $\left(\mu_{t}^{(1)}=5, \mu_{t}^{(2)}=10\right)$ (right)

\section{CONCLUSION}

This paper examined defaultable bond prices under the bivariate jump-diffusion model, whose jump sizes are dependent. The variables were the default intensity of a bond issuer and the short rate of interest, with exponentially distributed jump sizes and the dependence structure being captured by three copulas. The results indicated that the bond price under the Student-t copula showed the highest yield and had the widest range between both ends of the dependence parameters $\theta$, suggesting that it is a better candidate to represent a risky environment relative to the other two copulas. We also found that in comparison to the relatively safe environment, the bond yield values under the risky environment are very high, i.e. above $100 \%$, as the bond tenure increase up to 10 years, although both environments have an upward sloping term structure. It would be of interest to calibrate the model to the real bond data issued by a corporation to examine the dependency between its defaultability and short rate of interest, which we leave for further research.

\section{ACKNOWLEDGEMENTS}

The first author is grateful to the Ministry of Education Malaysia and Universiti Kebangsaan Malaysia for the support provided partially through the fund FRGS/1/2016/ STG06/UKM/03/1.

\section{REFERENCES}

Akhriadi, Black, F. \& Cox, J.C. 1976. Valuing corporate securities: Some effects of bond indenture provisions. Journal of Finance 31(2): 351-367.

Brigo, D. \& Chourdakis, K. 2009. Counterparty risk for credit default swap-Impact of spread volatility and default correlation. International Journal of Theoretical and Applied Finance 12(7): 1007-1026.
Cox, J.C., Ingersoll, J.E. \& Ross, S.A. 1985. A theory of the term structure of interest rates. Econometrica 53(2): 385-408.

Donelly, C. \& Embrechts, P. 2010. The devil is in the tails: Actuarial mathematics and the subprime mortgage crisis. ASTIN Bulletin 40(1): 1-33.

Duffie, D. \& Singleton, K. 1999. Modelling term structures of defaultable bonds. The Review of Financial Studies 12(4): 687-720.

Giesecke, K. 2004. Correlated default within complete information. Journal of Banking and Finance 28: 1521-1545.

Herbertsson, A., Jang, J. \& Schmidt, T. 2011. Pricing basket default swaps in a tractable shot noise model. Statistics \& Probability Letters 81(8): 1196-1207.

Hull, J. \& White, A. 1995. The impact of default risk on the prices of options and other derivative securities. Journal of Banking \& Finance 19(2): 299-322.

Hyong-Chol, O. \& Ning, W. 2005. Analytical pricing of defaultable bond with stochastic defaultintensity-The case with exogenous default recovery. Working Paper, Department of Applied Mathematics, Tong-ji University, Shanghai.

Ignatieva, K. \& Platen, E. 2010. Modelling co-movements and tail dependency in the international stock market via copulae. Asia-Pacific Financial Market 7(3): 261-304.

Jang, J. 2007. Jump-diffusion process and their applications in insurance and finance, Insurance: Mathematics and Economics 41(1): 62-70.

Jang, J. \& Mohd Ramli, S.N. 2018. Hierarchical Markov model in life insurance and social benefit schemes. Risks 6(3): 63. DOI: $10.3390 /$ risks6030063.

Jarrow, R.A. \& Protter, P. 2004. Structural versus reduced form models: A new information based perspective. Journal of Investment Management 2(2): 110.

Jarrow, R.A. \& Yu, F. 2001. Counterparty risk and the pricing of defaultable securities. Journal of Finance 56(5): 1765-1800.

Jarrow, R. \& Turnbull, S. 1995. Pricing derivatives on financial securities subject to credit risk. Journal of Finance 50(1): 53-85.

Jarrow, R., Lando, D. \& Turnbull, S.M. 1997. A Markov Model for the term structure of credit risk spreads. The Review of Financial Studies 10(2): 481-523. 
Jouanin, J.F., Rapuch, G., Riboulet, G. \& Roncalli, T. 2001. Modelling dependence for credit derivatives with copulas. Working Paper, Groupe de Recherche Opérationnelle, Crédit Lyonnais, France. http://dx.doi.org/10.2139/ssrn.1032561.

Kijima, M. 2000. Valuation of a credit swap of the basket type. Review of Derivatives Research 4(1): 81-97.

Lando, D. 1998. On cox processes and credit risky securities. Review of Derivatives Research 2(2): 99-120.

Li, D.X. 2000. On default correlation: A copula function approach. Journal of Fixed Income 9(4): 43-54.

Longstaff, S. \& Schwartz, E. 1995. A simple approach to valuing risky fixed and floating rate debt. Journal of Finance 50(3): 789-821.

Lund, S., Manyika, J., Mehta, A. \& Goldshtein, D. 2018. A decade after the global financial crisis: What has (and hasn't) changed? McKinsey Global Institute (Unpublished).

Ma, Y.K. \& Kim, J.H. 2010. Pricing the credit default swap rate for jump-diffusion default intensity processes. Quantitative Finance 10(8): 809-818.

Merton, R. 1974. On the pricing of corporate debt: The risk structure of interest rates. Journal of Finance 29(2): 449-470.

Mohd Ramli, S.N. \& Jang, J. 2015. A multivariate jump-diffusion process for counterparty risk in CDS rates. Journal of the Korean Society for Industrial and Applied Mathematics 19: 2345.

Mohd Ramli, S.N. \& Jang, J. 2014. Neumann series on the recursive moments of copula-dependent aggregate discounted claims. Risks 2(2): 195-210.

Nelsen, R.B. 2006. An Introduction to Copula. New York: Springer

Ruf, J. \& Scherer, M. 2011. Pricing corporate bonds in an arbitrary jump-diffusion model based on an improved Brownianbridge algorithm. Journal of Computational Finance 14(3): 127-144.
Salmon, F. 2009. Recipe for disaster: The formula that killed Wall Street. Wired Magazine. February 23, 2009.

Schmidt, T. 2006. Coping with Copula. In Copulas: From Theory to Application in Finance. London: Risk Books. pp.1-23.

Schonbucher, P.J. \& Schubert, D. 2001. Copula-dependent default risk in intensity models. Working Paper, Department of Statistics, Bonn University.

Shamiri, A., Hamzah, N. \& Pirmoradian, A. 2011. Tail dependence estimate in financial market risk management: Clayton-Gumbel copula approach. Sains Malaysiana 40(8): 927-935.

Stewart, I. 2012. The mathematical equation that caused the banks to crash. The Guardian. February 12, 2012.

Siti Norafidah Mohd Ramli*

Department of Mathematical Sciences

Faculty of Science and Technology

Universiti Kebangsaan Malaysia

43600 UKM Bangi, Selangor Darul Ehsan

Malaysia

Jiwook Jang

Department of Actuarial Studies and Business Analytics

Macquarie Business School

Macquarie University

North Ryde NSW 2109 Sydney

Australia

*Corresponding author; email: rafidah@ukm.edu.my

Received: 12 October 2019

Accepted: 23 December 2019

\section{A1: BOND PRICE AND YIELD AS A FUNCTION OF TENOR AND $\theta$ WITH Y $\sim \operatorname{Exp}(100,200)$}

APPENDIX 1. Prices of zero coupon bond under jump diffusion model with student-t copula dependence structure for years to

\begin{tabular}{cccccccccccc}
\multicolumn{10}{c}{ maturity $1-10$} \\
\hline$\theta$ & 1 & 2 & 3 & 4 & 5 & 6 & 7 & 8 & 9 & 10 \\
\hline-0.95 & 89.424 & 75.583 & 61.109 & 47.708 & 36.232 & 26.924 & 19.668 & 14.172 & 10.103 & 7.134 \\
-0.9 & 89.564 & 75.799 & 61.338 & 47.906 & 36.38 & 27.023 & 19.724 & 14.197 & 10.108 & 7.142 \\
-0.5 & 89.578 & 75.880 & 61.524 & 48.201 & 36.758 & 27.443 & 20.149 & 14.599 & 10.446 & 7.391 \\
0 & 90.002 & 76.521 & 62.185 & 48.758 & 37.161 & 27.693 & 20.273 & 14.6340 & 10.469 & 7.445 \\
0.5 & 90.030 & 76.678 & 62.410 & 48.983 & 37.366 & 27.870 & 20.420 & 14.751 & 10.538 & 7.461 \\
0.9 & 90.121 & 76.713 & 62.55 & 49.336 & 37.900 & 28.520 & 21.114 & 15.433 & 11.167 & 8.016 \\
0.95 & 90.151 & 76.885 & 62.805 & 49.609 & 38.168 & 28.767 & 21.333 & 15.620 & 11.322 & 8.1418
\end{tabular}


APPENDIX 2. Prices of zero coupon bond under jump diffusion model with Gaussian copula dependence structure for years to

\begin{tabular}{cccccccccccc}
\multicolumn{10}{c}{ maturity 1-10 } \\
\hline$\theta$ & 1 & 2 & 3 & 4 & 5 & 6 & 7 & 8 & 9 & 10 \\
\hline-0.95 & 92.529 & 82.015 & 70.281 & 58.598 & 47.798 & 38.312 & 30.283 & 23.673 & 18.343 & 14.114 \\
-0.9 & 92.530 & 82.016 & 70.284 & 58.602 & 47.803 & 38.318 & 30.290 & 23.680 & 18.350 & 14.121 \\
-0.5 & 92.626 & 82.157 & 70.518 & 58.933 & 48.148 & 38.657 & 30.609 & 23.971 & 18.609 & 14.346 \\
0 & 92.628 & 82.243 & 70.577 & 58.934 & 48.216 & 38.745 & 30.708 & 24.073 & 18.710 & 14.441 \\
0.5 & 92.631 & 82.255 & 70.608 & 58.986 & 48.221 & 38.787 & 30.788 & 24.180 & 18.831 & 14.558 \\
0.9 & 92.633 & 82.270 & 70.645 & 59.050 & 48.310 & 38.854 & 30.828 & 24.199 & 18.833 & 14.568 \\
0.95 & 92.634 & 82.284 & 70.680 & 59.110 & 48.394 & 38.956 & 30.942 & 24.316 & 18.949 & 14.668 \\
\hline
\end{tabular}

APPENDIX 3. Prices of zero coupon bond under jump diffusion model with FGM copula dependence structure for years to maturity

\begin{tabular}{cccccccccccc}
\hline \multicolumn{1}{c}{10} & \multicolumn{1}{c}{$1-10$} \\
\hline$\theta$ & 1 & 2 & 3 & 4 & 5 & 6 & 7 & 8 & 9 & 10 \\
\hline-0.95 & 92.627 & 82.332 & 70.805 & 59.332 & 48.714 & 39.358 & 31.400 & 24.804 & 19.442 & 15.146 \\
-0.9 & 92.627 & 82.332 & 70.806 & 59.334 & 48.716 & 39.361 & 31.404 & 24.808 & 19.445 & 15.149 \\
-0.5 & 92.627 & 82.336 & 70.814 & 59.349 & 48.736 & 39.386 & 31.431 & 24.837 & 19.474 & 15.177 \\
0 & 92.628 & 82.340 & 70.824 & 59.366 & 48.762 & 39.417 & 31.466 & 24.873 & 19.510 & 15.211 \\
0.5 & 92.629 & 82.344 & 70.835 & 59.384 & 48.787 & 39.448 & 31.501 & 24.909 & 19.546 & 15.246 \\
0.9 & 92.629 & 82.347 & 70.843 & 59.400 & 48.807 & 39.473 & 31.528 & 24.938 & 19.575 & 15.273 \\
0.95 & 92.629 & 82.347 & 70.844 & 59.401 & 48.810 & 39.476 & 31.532 & 24.942 & 19.579 & 15.279 \\
\hline
\end{tabular}

APPENDIX 4. Yield (in \%) of zero coupon bond under jump diffusion model with student-t copula dependence structure

\begin{tabular}{ccccccccccc}
\hline$\theta$ & 1 & 2 & 3 & 4 & 5 & 6 & 7 & 8 & 9 & 10 \\
\hline-0.95 & 11.827 & 15.024 & 17.842 & 20.324 & 22.513 & 24.445 & 26.152 & 27.665 & 29.008 & 30.217 \\
-0.9 & 11.652 & 14.860 & 17.695 & 20.200 & 22.413 & 24.369 & 26.101 & 27.637 & 29.002 & 30.202 \\
-0.5 & 11.635 & 14.799 & 17.576 & 20.015 & 22.160 & 24.050 & 25.717 & 27.192 & 28.530 & 29.756 \\
0 & 11.109 & 14.317 & 17.158 & 19.671 & 21.894 & 23.863 & 25.607 & 27.154 & 28.499 & 29.662 \\
0.5 & 11.074 & 14.199 & 17.017 & 19.533 & 21.760 & 23.731 & 25.477 & 27.027 & 28.406 & 29.634 \\
0.9 & 10.962 & 14.173 & 16.930 & 19.319 & 21.415 & 23.256 & 24.879 & 26.312 & 27.580 & 28.707 \\
0.95 & 10.925 & 14.046 & 16.771 & 19.155 & 21.244 & 23.079 & 24.695 & 26.122 & 27.386 & 28.507 \\
\hline
\end{tabular}

APPENDIX 5. Yield (in \%) of zero coupon bond under jump diffusion model with Gaussian copula dependence structure for years

\begin{tabular}{cccccccccccc}
\multicolumn{10}{c}{ to maturity $1-10$} \\
\hline$\theta$ & 1 & 2 & 3 & 4 & 5 & 6 & 7 & 8 & 9 & 10 \\
\hline-0.95 & 8.074 & 10.421 & 12.474 & 14.295 & 15.909 & 17.340 & 18.608 & 19.735 & 20.736 & 21.629 \\
-0.9 & 8.074 & 10.421 & 12.473 & 14.294 & 15.907 & 17.337 & 18.604 & 19.730 & 20.731 & 21.623
\end{tabular}




\begin{tabular}{ccccccccccc}
-0.5 & 7.961 & 10.326 & 12.348 & 14.133 & 15.740 & 17.164 & 18.427 & 19.547 & 20.543 & 21.430 \\
0 & 7.959 & 10.268 & 12.317 & 14.132 & 15.708 & 17.120 & 18.372 & 19.484 & 20.471 & 21.350 \\
0.5 & 7.956 & 10.260 & 12.301 & 14.107 & 15.705 & 17.099 & 18.328 & 19.418 & 20.384 & 21.252 \\
0.9 & 7.953 & 10.250 & 12.281 & 14.076 & 15.663 & 17.065 & 18.306 & 19.406 & 20.383 & 21.244 \\
0.95 & 7.952 & 10.241 & 12.263 & 14.047 & 15.622 & 17.014 & 18.244 & 19.334 & 20.301 & 21.161 \\
\hline
\end{tabular}

Appendix 6. Yield (in \%) of zero coupon bond under jump diffusion model with FGM copula dependence structure for years to maturity $1-10$

\begin{tabular}{ccccccccccc}
\hline$\theta$ & 1 & 2 & 3 & 4 & 5 & 6 & 7 & 8 & 9 & 10 \\
\hline-0.95 & 7.960 & 10.209 & 12.197 & 13.940 & 15.470 & 16.814 & 17.996 & 19.038 & 19.958 & 20.773 \\
-0.9 & 7.960 & 10.209 & 12.196 & 13.939 & 15.469 & 16.812 & 17.994 & 19.036 & 19.956 & 20.771 \\
-0.5 & 7.960 & 10.206 & 12.192 & 13.933 & 15.459 & 16.800 & 17.979 & 19.018 & 19.936 & 20.749 \\
0 & 7.959 & 10.204 & 12.186 & 13.924 & 15.448 & 16.785 & 17.961 & 18.996 & 19.911 & 20.721 \\
0.5 & 7.958 & 10.201 & 12.181 & 13.915 & 15.436 & 16.770 & 17.942 & 18.975 & 19.887 & 20.694 \\
0.9 & 7.957 & 10.197 & 12.176 & 13.908 & 15.426 & 16.757 & 17.927 & 18.957 & 19.867 & 20.672 \\
0.95 & 7.957 & 10.198 & 12.176 & 13.908 & 15.425 & 16.756 & 17.922 & 18.955 & 19.865 & 20.670 \\
\hline
\end{tabular}

A2: BOND PRICE AND YIELD AS A FUNCTION OF TENOR AND $\theta$ WITH Y Exp(5,10)

APPENDIX 7. Prices of zero coupon bond under jump diffusion model with student-t copula dependence structure for years to

\begin{tabular}{ccccccccccc}
\hline \multicolumn{10}{c}{ maturity $1-10$} \\
\hline$\theta$ & 1 & 2 & 3 & 4 & 5 & 6 & 7 & 8 & 9 & 10 \\
\hline-0.95 & 51.019 & 11.845 & 1.732 & 0.188 & 0.017 & 0.001 & $8.80 \mathrm{E}-05$ & $5.6 \mathrm{E}-06$ & $3.4 \mathrm{E}-07$ & $2.0 \mathrm{E}-08$ \\
-0.9 & 51.030 & 11.893 & 1.751 & 0.192 & 0.017 & 0.001 & $9.4 \mathrm{E}-05$ & $6.1 \mathrm{E}-06$ & $3.7 \mathrm{E}-07$ & $2.2 \mathrm{E}-08$ \\
-0.5 & 51.275 & 12.348 & 1.928 & 0.228 & 0.0224 & 0.002 & 0.0002 & $1.1 \mathrm{E}-05$ & $7.6 \mathrm{E}-07$ & $5.1 \mathrm{E}-08$ \\
0 & 51.867 & 13.089 & 2.204 & 0.287 & 0.0314 & 0.003 & 0.0003 & $2.3 \mathrm{E}-05$ & $1.8 \mathrm{E}-06$ & $1.4 \mathrm{E}-07$ \\
0.5 & 52.791 & 14.085 & 2.578 & 0.372 & 0.046 & 0.005 & 0.0005 & $4.9 \mathrm{E}-05$ & $4.4 \mathrm{E}-06$ & $3.9 \mathrm{E}-07$ \\
0.9 & 53.883 & 15.191 & 3.010 & 0.478 & 0.065 & 0.008 & 0.0009 & $9.9 \mathrm{E}-05$ & $1.0 \mathrm{E}-05$ & $1.0 \mathrm{E}-06$ \\
0.95 & 54.065 & 15.368 & 3.080 & 0.496 & 0.069 & 0.009 & 0.001 & 0.0001 & $1.1 \mathrm{E}-05$ & $1.2 \mathrm{E}-06$ \\
\hline
\end{tabular}

Appendix 8. Prices of zero coupon bond under jump diffusion model with Gaussian copula dependence structure for years to maturity $1-10$

\begin{tabular}{cccccccccccc}
\hline$\theta$ & 1 & 2 & 3 & 4 & 5 & 6 & 7 & 8 & 9 & 10 \\
\hline-0.95 & 57.359 & 15.816 & 2.736 & 0.347 & 0.036 & 0.003 & 0.00024 & $1.7 \mathrm{E}-05$ & $1.2 \mathrm{E}-06$ & $7.6 \mathrm{E}-08$ \\
-0.9 & 57.387 & 15.862 & 2.757 & 0.352 & 0.036 & 0.003 & 0.0003 & $1.8 \mathrm{E}-05$ & $1.3 \mathrm{E}-06$ & $8.2 \mathrm{E}-08$ \\
-0.5 & 57.669 & 16.283 & 2.944 & 0.396 & 0.044 & 0.004 & 0.0004 & $2.8 \mathrm{E}-05$ & $2.1 \mathrm{E}-06$ & $1.5 \mathrm{E}-07$ \\
0 & 58.036 & 16.873 & 3.215 & 0.465 & 0.056 & 0.006 & 0.0006 & $4.9 \mathrm{E}-05$ & $4.1 \mathrm{E}-06$ & $3.3 \mathrm{E}-07$ \\
0.5 & 58.470 & 17.562 & 3.541 & 0.552 & 0.072 & 0.008 & 0.0009 & $8.7 \mathrm{E}-05$ & $8.1 \mathrm{E}-06$ & $7.4 \mathrm{E}-07$
\end{tabular}




$\begin{array}{lllllllllll}0.9 & 58.866 & 18.195 & 3.852 & 0.639 & 0.09 & 0.011 & 0.00130 & 0.00014 & 1.4 \mathrm{E}-05 & 1.4 \mathrm{E}-06 \\ 0.95 & 58.87 & 18.251 & 3.885 & 0.650 & 0.092 & 0.012 & 0.00136 & 0.00015 & 1.5 \mathrm{E}-05 & 1.6 \mathrm{E}-06\end{array}$

Appendix 9. Prices of zero coupon bond under jump diffusion model with FGM copula dependence structure for years to maturity

\begin{tabular}{cccccccccccc}
\hline \multicolumn{1}{c}{} & \multicolumn{10}{c}{$1-10$} \\
\hline$\theta$ & 1 & 2 & 3 & 4 & 5 & 6 & 7 & 8 & 9 & 10 \\
\hline-0.95 & 57.797 & 16.488 & 3.036 & 0.419 & 0.048 & 0.005 & 0.0004 & $3.4 \mathrm{E}-05$ & $2.7 \mathrm{E}-06$ & $2.0 \mathrm{E}-07$ \\
-0.9 & 57.810 & 16.508 & 3.045 & 0.422 & 0.048 & 0.005 & 0.0004 & $3.5 \mathrm{E}-05$ & $2.7 \mathrm{E}-06$ & $2.1 \mathrm{E}-07$ \\
-0.5 & 57.910 & 16.669 & 3.120 & 0.440 & 0.051 & 0.005 & 0.0005 & $4.1 \mathrm{E}-05$ & $3.3 \mathrm{E}-06$ & $2.5 \mathrm{E}-07$ \\
0 & 58.036 & 16.873 & 3.215 & 0.465 & 0.056 & 0.006 & 0.001 & $4.9 \mathrm{E}-05$ & $4.1 \mathrm{E}-06$ & $3.3 \mathrm{E}-07$ \\
0.5 & 58.163 & 17.079 & 3.313 & 0.491 & 0.060 & 0.007 & 0.001 & $5.9 \mathrm{E}-05$ & $5.1 \mathrm{E}-06$ & $4.3 \mathrm{E}-07$ \\
0.9 & 58.264 & 17.246 & 3.394 & 0.512 & 0.065 & 0.007 & 0.001 & $6.9 \mathrm{E}-05$ & $6.2 \mathrm{E}-06$ & $5.3 \mathrm{E}-07$ \\
0.95 & 58.277 & 17.267 & 3.404 & 0.515 & 0.065 & 0.007 & 0.001 & $7.0 \mathrm{E}-05$ & $6.3 \mathrm{E}-06$ & $5.5 \mathrm{E}-07$
\end{tabular}

Appendix 10. Yield (in \%) of zero coupon bond under jump diffusion model with student-t copula dependence structure for years to maturity $1-10$

\begin{tabular}{cccccccccccc}
\hline$\theta$ & 1 & 2 & 3 & 4 & 5 & 6 & 7 & 8 & 9 & 10 \\
\hline-0.95 & 96.006 & 190.56 & 286.50 & 380.36 & 470.04 & 554.41 & 633.00 & 705.74 & 772.80 & 834.48 \\
-0.9 & 95.963 & 189.97 & 285.05 & 377.81 & 466.23 & 549.27 & 626.50 & 697.90 & 763.65 & 824.08 \\
-0.5 & 95.028 & 184.58 & 272.96 & 357.58 & 437.05 & 510.80 & 578.75 & 641.07 & 698.11 & 750.24 \\
0 & 92.802 & 176.40 & 256.69 & 332.05 & 401.77 & 465.72 & 524.12 & 577.28 & 625.64 & 669.63 \\
0.5 & 89.425 & 166.46 & 238.52 & 304.91 & 365.51 & 420.53 & 470.36 & 515.45 & 556.23 & 593.17 \\
0.9 & 85.587 & 156.57 & 221.48 & 280.36 & 333.49 & 381.32 & 424.34 & 463.06 & 499.34 & 530.85 \\
0.95 & 84.961 & 155.09 & 219.01 & 276.86 & 328.98 & 375.85 & 417.93 & 456.18 & 490.39 & 521.65 \\
\hline
\end{tabular}

Appendix 14. Yield (in \%) of zero coupon bond under jump diffusion model with Gaussian copula dependence structure for years

to maturity $1-10$

\begin{tabular}{ccccccccccccccc}
\hline$\theta$ & 1 & 2 & 3 & 4 & 5 & 6 & 7 & 8 & 9 \\
\hline-0.95 & 74.340 & 151.45 & 231.86 & 312.16 & 390.11 & 464.40 & 534.33 & 599.63 & 660.27 & 716.40 \\
-0.9 & 74.255 & 151.09 & 231.02 & 310.69 & 387.91 & 461.40 & 530.51 & 594.97 & 654.80 & 710.13 \\
-0.5 & 73.405 & 147.82 & 223.88 & 298.54 & 370.03 & 437.40 & 500.23 & 558.45 & 612.17 & 661.62 \\
0 & 72.306 & 143.45 & 214.50 & 282.99 & 347.64 & 407.88 & 463.55 & 514.75 & 561.72 & 604.73 \\
0.5 & 71.029 & 138.62 & 204.52 & 266.92 & 325.00 & 378.54 & 427.61 & 472.44 & 513.32 & 550.59 \\
0.9 & 69.880 & 134.44 & 196.11 & 253.64 & 306.59 & 354.99 & 399.04 & 439.07 & 475.41 & 508.42 \\
0.95 & 69.866 & 134.08 & 195.26 & 252.22 & 304.58 & 352.36 & 395.83 & 435.29 & 471.11 & 503.63 \\
\hline
\end{tabular}


Appendix 12. Yield (in \%) of zero coupon bond under jump diffusion model with FGM copula dependence structure for years to

\begin{tabular}{ccccccccccc}
\multicolumn{10}{c}{ maturity $1-10$} \\
\hline$\theta$ & 1 & 2 & 3 & 4 & 5 & 6 & 7 & 8 & 9 & 10 \\
\hline-0.95 & 73.019 & 146.27 & 220.54 & 292.99 & 362.01 & 426.79 & 487.01 & 542.67 & 593.91 & 641.00 \\
-0.9 & 72.982 & 146.12 & 220.22 & 292.46 & 361.24 & 425.78 & 485.75 & 541.17 & 592.18 & 639.05 \\
-0.5 & 72.681 & 144.93 & 217.67 & 288.22 & 355.15 & 417.74 & 475.78 & 529.29 & 578.47 & 623.59 \\
0 & 72.306 & 143.45 & 214.50 & 282.99 & 347.64 & 407.88 & 463.55 & 514.75 & 561.72 & 604.73 \\
0.5 & 71.931 & 141.97 & 211.36 & 277.83 & 340.26 & 398.20 & 451.58 & 500.55 & 545.37 & 586.35 \\
0.9 & 71.632 & 140.80 & 208.88 & 273.75 & 334.44 & 390.59 & 442.19 & 489.43 & 532.59 & 572.00 \\
0.95 & 71.595 & 140.65 & 208.57 & 273.25 & 333.72 & 389.64 & 441.02 & 488.05 & 531.01 & 570.23 \\
\hline
\end{tabular}

